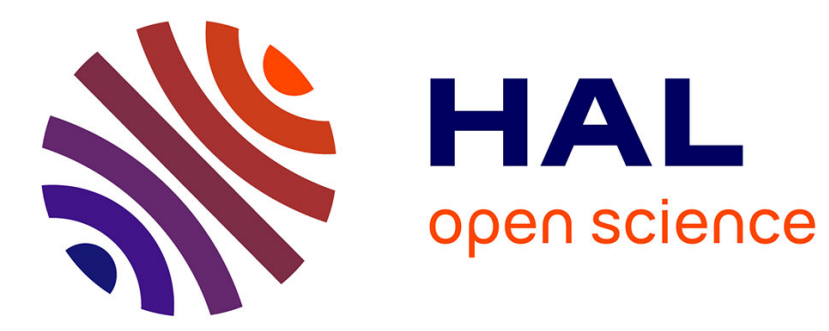

\title{
Optimisation of tree path pipe network with nonlinear optimisation method
}

D. Dobersek, D. Goricanec

\section{To cite this version:}

D. Dobersek, D. Goricanec. Optimisation of tree path pipe network with nonlinear optimisation method. Applied Thermal Engineering, 2009, 29 (8-9), pp.1584. 10.1016/j.applthermaleng.2008.07.017 . hal-00581929

\section{HAL Id: hal-00581929 \\ https://hal.science/hal-00581929}

Submitted on 1 Apr 2011

HAL is a multi-disciplinary open access archive for the deposit and dissemination of scientific research documents, whether they are published or not. The documents may come from teaching and research institutions in France or abroad, or from public or private research centers.
L'archive ouverte pluridisciplinaire HAL, est destinée au dépôt et à la diffusion de documents scientifiques de niveau recherche, publiés ou non, émanant des établissements d'enseignement et de recherche français ou étrangers, des laboratoires publics ou privés. 


\section{Accepted Manuscript}

Optimisation of tree path pipe network with nonlinear optimisation method

D. Dobersek, D. Goricanec

PII:

S1359-4311(08)00312-8

DOI:

10.1016/j.applthermaleng.2008.07.017

Reference:

ATE 2575

To appear in:

Applied Thermal Engineering

\section{APPLIED}

THERMAL

ENGINEERING

6 November 2006

Received Date:

18 February 2008

Revised Date:

10 July 2008

Accepted Date:

Please cite this article as: D. Dobersek, D. Goricanec, Optimisation of tree path pipe network with nonlinear optimisation method, Applied Thermal Engineering (2008), doi: 10.1016/j.applthermaleng.2008.07.017

This is a PDF file of an unedited manuscript that has been accepted for publication. As a service to our customers we are providing this early version of the manuscript. The manuscript will undergo copyediting, typesetting, and review of the resulting proof before it is published in its final form. Please note that during the production process errors may be discovered which could affect the content, and all legal disclaimers that apply to the journal pertain. 


\title{
Optimisation of tree path pipe network with nonlinear optimisation method
}

\author{
D. Dobersek* ${ }^{*}$ D. Goricanec \\ Faculty of Chemistry and Chemical Engineering, University of Maribor, \\ Smetanova ul. 17, 2000 Maribor, Slovenia
}

\begin{abstract}
In this article the optimisation of pipe network with hot water is presented. The mathematical model, consisting of the non - linear objective function and system of non - linear equations for the hydraulics limitations is developed. On its basis the computer program for determination optimal tree path with the use of simplex method was solved. For economic estimation the capitalized value method, which consider all costs of investment and operation was used. The results are presented for real case study network with 24 nodes and 33 pipe sectors.
\end{abstract}

Keywords: District heating; Pipe network; Optimisation; Non-linear programming; Simplex method

\section{Introduction}

Nowadays efforts connected to energy savings demand the search for new technical scientific expertise in the field of heating techniques $[1-4]$. The focus of research is on better and more efficient use of primary energy [5].

*Corresponding author.

Tel.: 0038622207 761; fax: 0038622294476.

E-mail address: danijela.dobersek@uni-mb.si (D. Dobersek).
If we limit ourselves to district heating energy systems, we may state that these systems ensure savings in the process of use of primary energy and are acceptable from the ecological point of view. 


\begin{tabular}{|c|c|c|c|}
\hline \multicolumn{4}{|l|}{ Nomenclature } \\
\hline$A, B, C, D, E, F$ & constants & $L$ & pipe length \\
\hline$A C$ & annuity costs & $L_{0}$ & salvage value \\
\hline$B_{0}$ & investment costs & $n$ & device lifetime \\
\hline$C C$ & capitalized costs & $N_{v}$ & number of nodes \\
\hline$C_{0}$ & operating and maintenance costs & $N_{c}$ & number of pipes \\
\hline$C_{1}$ & pipe network expenditure & $p$ & pressure \\
\hline$C_{2}$ & pump investment expenditure & $P$ & power \\
\hline$C_{3}$ & pumping costs & $\operatorname{Re}$ & Reynolds number \\
\hline$C_{4}$ & construction expenditure & $t$ & operating time of pipe network \\
\hline$C_{\mathrm{e}}$ & electric price & $v$ & velocity \\
\hline$C\left(q_{\mathrm{v}}\right)$ & objective function & $q_{v}$ & flow volume \\
\hline$C_{\mathrm{p}}$ & pump price & & \\
\hline$d$ & pipe diameter & Greek symbols & \\
\hline$i$ & interest rate & $\rho$ & density \\
\hline$k$ & pipe roughness & $\lambda$ & friction factor \\
\hline$K$ & coefficient of Darcy - Weisbach equation & $\zeta$ & coefficient of local losses \\
\hline & & $\eta$ & pump efficiency \\
\hline
\end{tabular}

The whole system is represented as a non-linear target function by non-linear equations of hydraulic limitations and by minimizing the non-linear function the optimal design and dimensions of the pipe network are defined $[6,7]$.

One method for modelling pipe networks is by linear programming, consisting of optimisation with limitations [8], meaning the search for the best possible, optimal solution of the stated problem within given conditions.
Nowadays two methods for solving linear programmes are used, both of them interactive, searching for a gradually better solution, until the optimum value is achieved. Mostly, simplex methods focused on searching for permissible solutions within the monotonous defined extreme point of the convex polyhedron of possible solutions and a defined base of the vector space, are used. 


\section{ACCEPTED MANUSCRIPT}

\section{District heating systems}

District heating systems are intended for the distribution of heat energy by a fluid from a heating source to different users $[9,10,11]$. The pressure losses of the system are defined by the non-linear Darcy-Weisbach equation [12]:

$$
p_{i}-p_{j}=0.81 \cdot \frac{\rho \cdot q_{\mathrm{vij}}^{2}}{d^{4}} \cdot\left(\frac{\lambda \cdot L}{d}+\sum \zeta\right)=K_{\mathrm{ij}} \cdot q_{\mathrm{vij}}^{2}
$$

The Darcy friction coefficient $(\lambda)$ is a function of the Reynolds number. In the range of the laminar flow the pressure losses depend only on the fluid viscosity, but in the range of turbulent flow the decisive factor is the relative pipe roughness coefficient, which depends upon age, corrosion and pipe material.

The relative pipe roughness coefficient $(\mathrm{k} / \mathrm{d})$ is a relation between absolute roughness of the inner pipe wall and the inner pipe diameter.

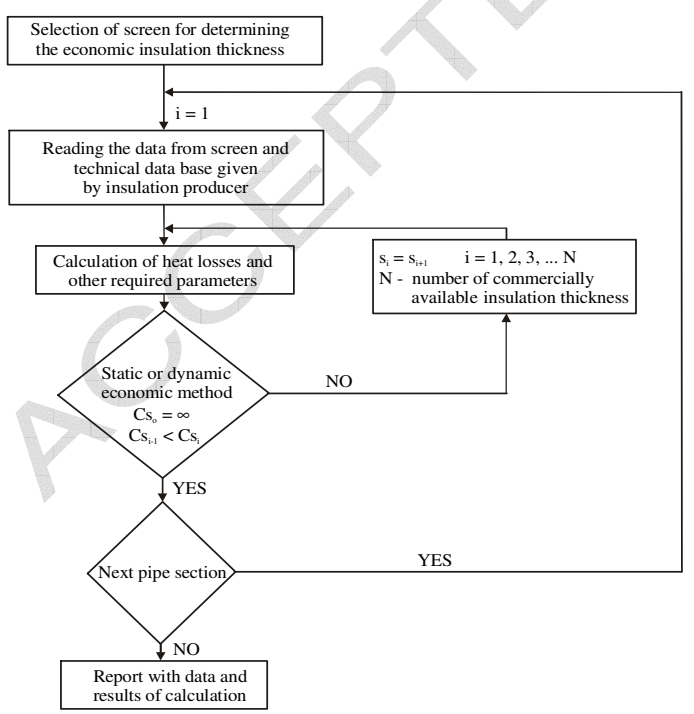

Figure 1: Simplified flow diagram for optimal thermal insulation thickness $\left(\mathrm{c}_{\mathrm{s}}-\right.$ insulation costs)
The heat losses through the pipes are negligible. Optimal thickness of insulation was calculated with the help of developed computer program [13]. The program flow diagram is presented on figure 1 , and the difference between the static and dynamic economic methods on figure 2.

STATIC METHOD
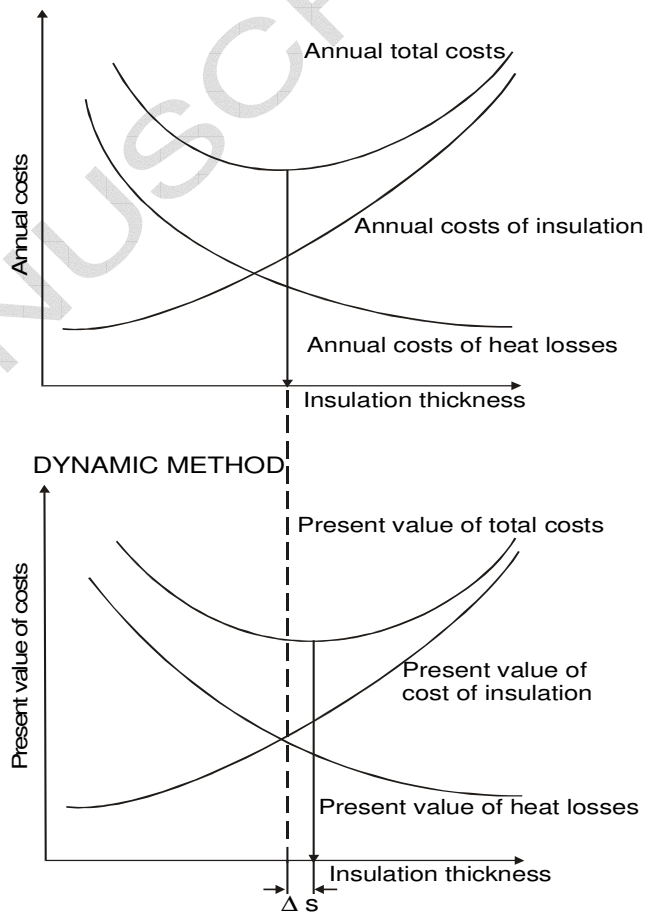

Figure 2: The difference between the static and dynamic economic methods by determining the economic thermal insulation thickness

\section{The linear programming method}

At the beginning the optimisation problem has to be designed. The common configuration of the mathematical model of the linear optimisation problem with $\mathrm{m}$ limitations and $\mathrm{n}$ variables is $[14,15]$ : 
objective function $\min \left(\mathrm{c}_{1} \cdot x_{1}+\mathrm{c}_{2} \cdot x_{2}+\ldots+\mathrm{c}_{\mathrm{n}} \cdot x_{\mathrm{n}}\right)$ limitation

$$
\begin{array}{cc}
\mathrm{a}_{11} \cdot x_{1}+\mathrm{a}_{12} \cdot x_{2}+\ldots+\mathrm{a}_{1 \mathrm{n}} \cdot x_{\mathrm{n}} & (\leq, \geq,=) \mathrm{b}_{1} \\
\mathrm{a}_{21} \cdot x_{1}+\mathrm{a}_{22} \cdot x_{2}+\ldots+\mathrm{a}_{2 \mathrm{n}} \cdot x_{\mathrm{n}} & (\leq, \geq,=) \mathrm{b}_{2} \\
\vdots & \vdots \\
\mathrm{a}_{\mathrm{m} 1} \cdot x_{1}+\mathrm{a}_{\mathrm{m} 2} \cdot x_{2}+\ldots+\mathrm{a}_{\mathrm{mn}} \cdot x_{\mathrm{n}} & (\leq, \geq,=) \mathrm{b}_{\mathrm{m}} \\
x_{1}, x_{2}, \ldots, x_{\mathrm{m}} \geq 0 &
\end{array}
$$

The mathematical model (2) is soluble with a simplex algorithm [16].

The conditions in the form of non-equations are transferred into equations by introducing additional variables.

$$
\mathrm{a}_{11} \cdot x_{1}+\mathrm{a}_{12} \cdot x_{2}+\ldots+\mathrm{a}_{1 \mathrm{n}} \cdot x_{\mathrm{n}} \geq \mathrm{b}_{1}
$$

The possible surplus is subtracted and the non-equation becomes an equation:

$$
\mathrm{a}_{11} \cdot x_{1}+\ldots+\mathrm{a}_{1 \mathrm{n}} \cdot x_{\mathrm{n}}-x_{\mathrm{n}+1}=\mathrm{b}_{1}
$$

The additional variable $\left(x_{\mathrm{n}+1}\right)$ was added and we now have to consider this with conditions, but it has no influence on the objective function due to the fact that its coefficient $\left(c_{n+1}\right)$ is zero.

This modified linear programme is complemented with artificial variables $\left(x_{n+m+1}\right)$ to find the primary interior point where the simplex calculations are to begin.

$$
\mathrm{a}_{11} \cdot x_{1}+\ldots+\mathrm{a}_{1 \mathrm{n}} \cdot x_{\mathrm{n}}-x_{\mathrm{n}+1}+x_{\mathrm{n}+\mathrm{m}+1}=\mathrm{b}_{1}
$$

We complement the objective function with a new variable and ascribe to it the coefficient $\left(\mathrm{c}_{\mathrm{n}+\mathrm{m}+1}\right)$ :

$$
\begin{aligned}
\mathrm{c}= & \mathrm{c}_{1} \cdot x_{1}+\ldots+\mathrm{c}_{\mathrm{n}} \cdot x_{\mathrm{n}}+\mathrm{c}_{\mathrm{n}+1} \cdot x_{\mathrm{n}+1}+ \\
& +\ldots+\mathrm{c}_{\mathrm{n}+\mathrm{m}} \cdot x_{\mathrm{n}+\mathrm{m}}+\mathrm{c}_{\mathrm{n}+\mathrm{m}+1} \cdot x_{\mathrm{n}+\mathrm{m}+1}
\end{aligned}
$$

The artificial variables serve for determination of the base allowed solution. In the last step the objective function is transferred from the minimum type to the maximum type:

$$
-\mathrm{c}=\sum_{\mathrm{j}=1}^{\mathrm{n}}-\mathrm{c}_{\mathrm{j}} \cdot x_{\mathrm{j}}
$$

Due to the fact that the first result is not necessarily optimal, we execute the optimality test. If the solution is not optimal a new base is required.

\section{Optimisation of pipe network}

For an effective and accurate description we handle the pipe network as a linear, directed graph, where the fluid entrance points are named as supplied nodes, fluid exit points are user nodes and the nodes where no external inflow or outflow is present as fictive nodes $[17,18]$.

If we define the number of pipes as $\mathrm{N}_{\mathrm{c}}$ and $\mathrm{N}_{\mathrm{v}}$ as the number of nodes for the tree pipe network then the number of nodes is always less than the number of pipes for the structure with loops.

The fluid flow in the net has the direction from the node with higher pressure to the node with lower pressure and is from $\mathrm{i}$ to $\mathrm{j}$ positive and in the other direction negative. With that we have to consider the first Kirchoff s law which says that the sum of all flows into a node equals the sum of all outflows. 
The optimal path with minimal transport costs can be defined by two methods of linear programming, the transport method and the simplex method.

Garbai and Krope present a graph-theoretical method to set up a network with optimum operational costs. Their method is based on the Bellmann optimum principle and the application of discreet dynamic programming [19].

The mathematical model for defining the optimal tree path consists of the objective function of capitalised costs $C\left(q_{\mathrm{v}}\right)$ that is minimised.

Capitalised costs of each pipe $C C_{\mathrm{j}}$ are the sums of discounted values of investment in pipes, pumps, building expenses and operational costs. As the capitalised costs depend on the pipe diameter, which is discreet variable, and the diameters depend on the flow, the object function is non-linear.

$$
\min C\left(q_{\mathrm{v}}\right)=\sum_{\mathrm{j}=1}^{\mathrm{N}_{c}} C C_{\mathrm{j}} \cdot q_{\mathrm{vj}}
$$

Further elements of the mathematical model are nonlinear equations of hydraulic limitations that represent the continuity of the pipe network and limitations of the simplex method representing the required no- negativity of the simplex variables.

$$
\begin{aligned}
& q_{v 1}-\sum_{i=2}^{N_{v}} q_{v i}=0 \\
& \sum_{j=1}^{N_{c}} \pm q_{v i j} \pm q_{v i}=0\left(i=1,2,3, \ldots, N_{v}\right) \\
& q_{v i j} \geq 0 \quad\left(i=1,2,3 \ldots, N_{v} j=1,2,3, \ldots, N_{c}\right)
\end{aligned}
$$

Figure 3 shows the nonlinear relationship between capitalised costs and volume flow.

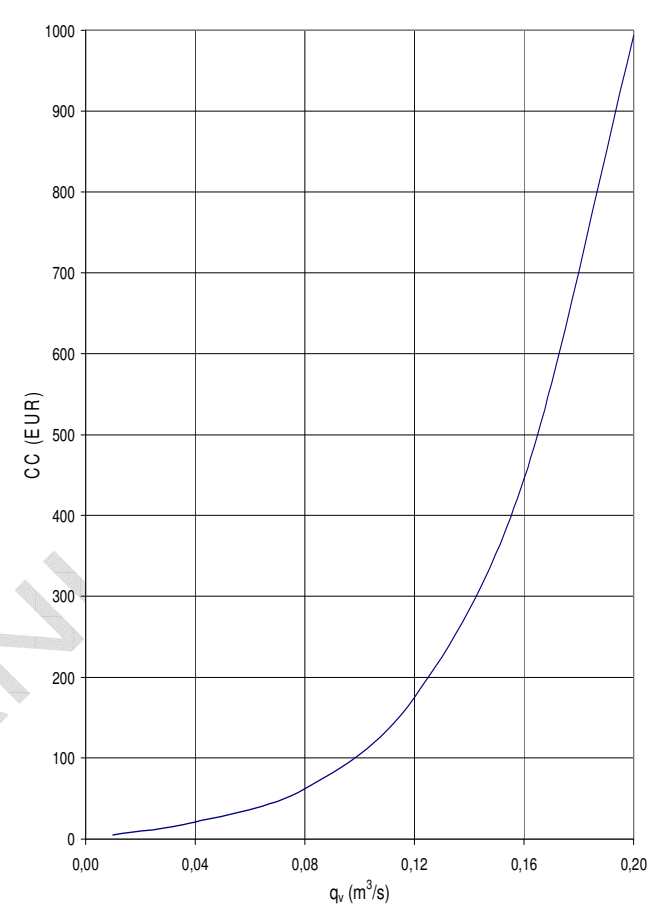

Figure 3: Relationship between CC and $\mathrm{q}_{\mathrm{v}}$

\section{The financial analyse of district heating system}

As the lifetime of warm water pipe networks is limited, let us suppose that after that lifetime the network is substituted by a new one. Pumps needed to transport fluids through the pipe network have an essential shorter lifetime than the pipe itself. If we are going to evaluate the project with the future or present value method the overall lifetime of all equipment parts has to be known. The capitalised costs method is used; including all costs of investment and operation to infinity [20]. The capitalised costs are the 
present value of investment costs repeating to infinity and are presented as formula:

$$
C C=B_{0}+\frac{B_{0}-L_{0}}{(1+i)^{n}-1}+\frac{C_{0}}{i}
$$

And the equation (10) became equation (11):

$$
C C=L_{0}+\frac{B_{0}-L_{0}}{1-(1+i)^{-n}}+\frac{C_{0}}{i}
$$

Regarding capitalised costs the annuities are defined, based on a discount rate and composed of the sum of all costs and revenues transposed to equal yearly shares. Within defining the annual costs they start from the start of the pipe network operation and end with the closure of the pipe network operation and are presented at the end of each year in equal portions. Between the annuity costs and capitalised costs the following dependence is valid:

$$
A C=C C \cdot i
$$

Defining the fluid transport costs over the pipe network we have to consider that the initial investment costs are very high. In the first step we define the costs of insulated pipes that are a function of the diameter with the following equation:

$$
C_{1}=A+B \cdot d+C \cdot d^{2}
$$

The conversion on standard diameters is done with the use of economic method and is presented in [21].

The investment value for pumps depends on the utilisation rate and the pump price calculated per watt of power, the flow volume and the pressure drop that arises with the increase in pump capacity.

$$
C_{2}=C_{\mathrm{p}} \cdot P=C_{\mathrm{p}} \cdot \frac{q_{\mathrm{v}} \cdot \Delta p}{\eta}
$$

The pumping costs depend on the electrical energy price, the pump power and the operational lifetime of the pipeline.

$$
C_{3}=C_{\mathrm{e}} \cdot P \cdot t
$$

The construction costs depend on pipe diameter in defined pipe sectors and on the construction site environment of the pipe network.

$$
\begin{aligned}
& C_{4}=D+E \cdot d+F \cdot d^{2} \\
& \sum C=C_{1}+C_{2}+C_{3}+C_{4}
\end{aligned}
$$

Figure 4 shows the relationship between the pipe costs, pump and pumping costs and costs for constructions.

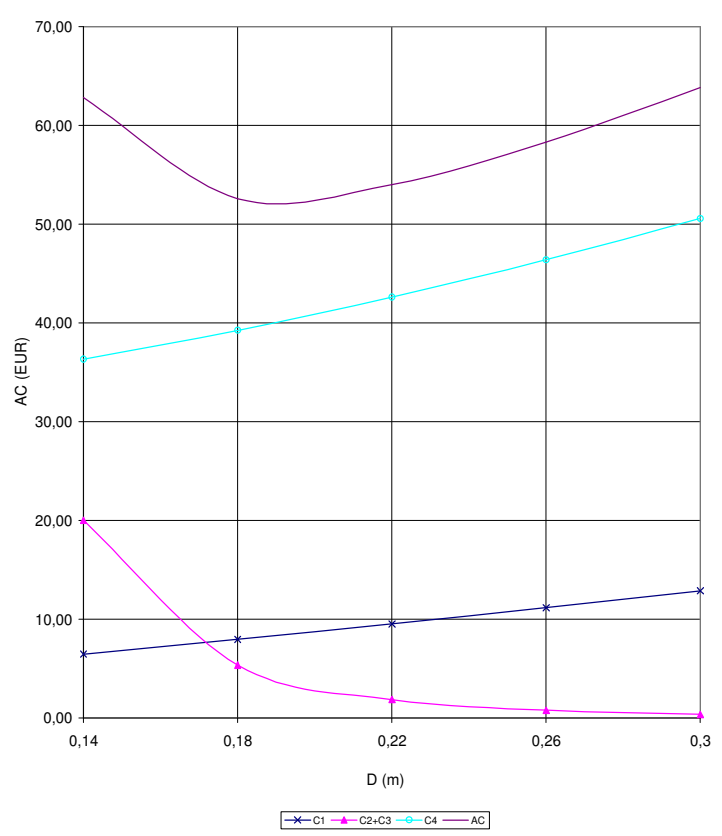

Figure 4: Relationship between all annuity costs vs. pipe diameter for the $\mathrm{q}_{\mathrm{v}}=0.04 \mathrm{~m}^{3} / \mathrm{s}$ and $\mathrm{L}=1 \mathrm{~m}$ 


\section{ACCEPTED MANUSCRIPT}

Figure 5 presents the algorithm for determining the optimal branch tree path and pipe diameters with the use of developed computer program.

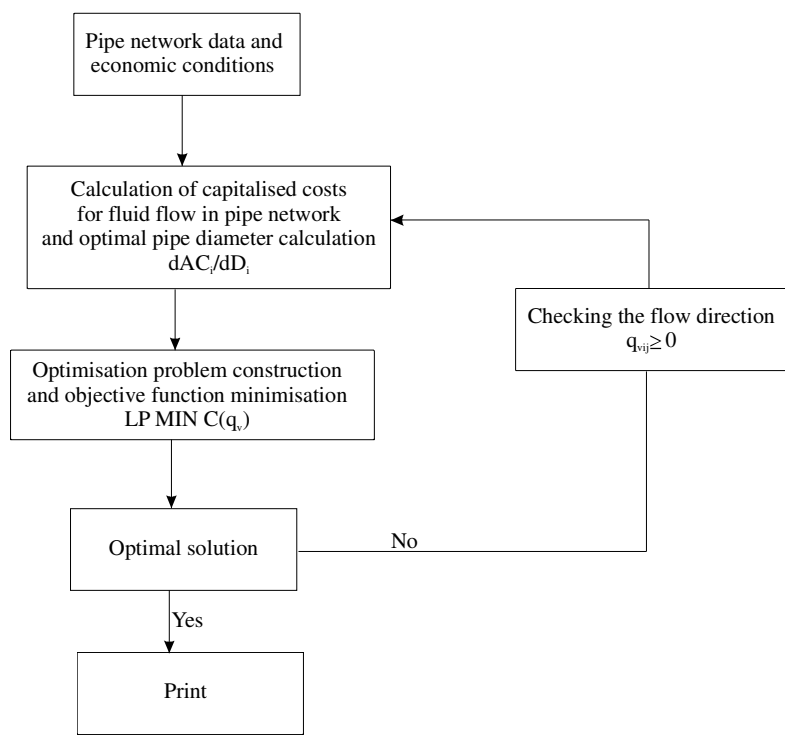

Figure 5: Algorithm for determining the optimal branch tree path and pipe diameters

\section{The Optimisation of the District Heating System}

The simplex method and the capitalised costs method were used for the optimisation of the district heating system (Figure 6).

The network consists of 33 pipeline sectors and 24 nodes. Hot water flowing at high pressure enters the system in the node TOM1 and exits in T3, T4, T8, T9, T10, T12, T13, T15, T20 and T22, other nodes on figure 3 are virtual, and represent the branching of pipes.

Data needed for the optimisation of the pipe network are presented in tables 1, 2 and 3.

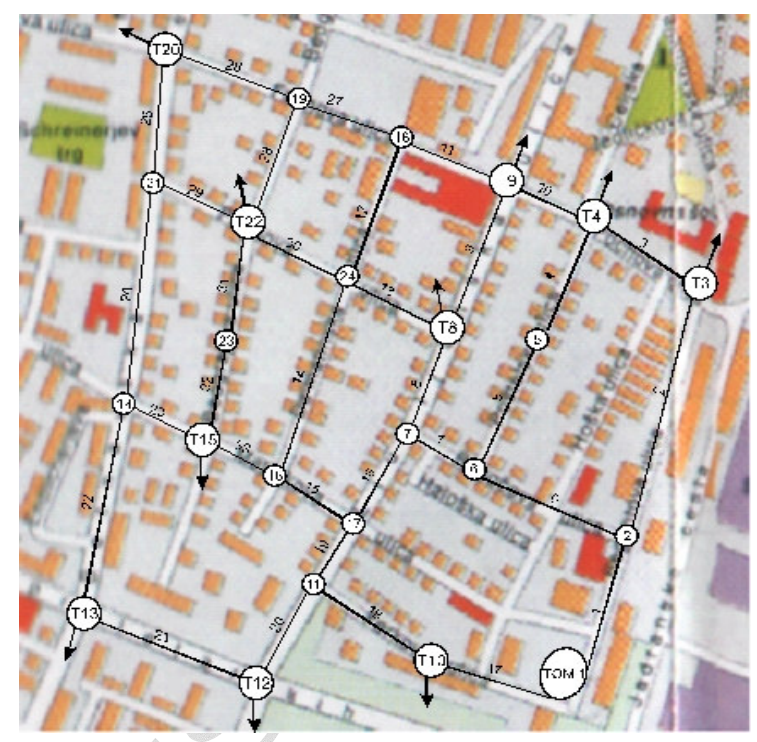

Figure 6:Loop pipe network of all possible routes of the district heating system

Table 1: Pipe data

\begin{tabular}{|c|c|c|}
\hline Pipe & $\mathrm{L}[\mathrm{m}]$ & $\zeta$ \\
\hline 1 & 210 & 10 \\
\hline 2 & 400 & 5 \\
\hline 3 & 150 & 5 \\
\hline 4 & 200 & 15 \\
\hline 5 & 200 & 5 \\
\hline 6 & 220 & 5 \\
\hline 7 & 100 & 5 \\
\hline 8 & 160 & 5 \\
\hline 9 & 210 & 15 \\
\hline 10 & 90 & 5 \\
\hline 11 & 140 & 5 \\
\hline 12 & 210 & 5 \\
\hline 13 & 150 & 15 \\
\hline 14 & 320 & 5 \\
\hline 15 & 110 & 10 \\
\hline 16 & 130 & 10 \\
\hline 17 & 160 & 5 \\
\hline 18 & 180 & 15 \\
\hline 19 & 90 & 5 \\
\hline 20 & 140 & 15 \\
\hline 21 & 230 & 5 \\
\hline 22 & 310 & 5 \\
\hline 23 & 90 & 10 \\
\hline 24 & 340 & 5 \\
\hline 25 & 180 & 5 \\
\hline 26 & 180 & 10 \\
\hline 27 & 150 & 5 \\
\hline 28 & 170 & 15 \\
\hline 29 & 120 & 10 \\
\hline 30 & 160 & 5 \\
\hline 31 & 150 & 15 \\
\hline 32 & 120 & 10 \\
\hline 33 & 80 & 5 \\
\hline
\end{tabular}




\section{ACCEPTED MANUSCRIPT}

Table 2: Input and output data in nodes

\begin{tabular}{|c|c|}
\hline Node & $\mathrm{q}_{\mathrm{v}} \times 10^{-3}\left[\mathrm{~m}^{3} / \mathrm{s}\right]$ \\
\hline 1 & 47.50 \\
\hline 2 & 0 \\
\hline 3 & -2.20 \\
\hline 4 & -7.60 \\
\hline 5 & 0 \\
\hline 6 & 0 \\
\hline 7 & 0 \\
\hline 8 & -9.8 \\
\hline 9 & -7.3 \\
\hline 10 & -3.4 \\
\hline 11 & 0 \\
\hline 12 & -4.8 \\
\hline 13 & -5.2 \\
\hline 14 & 0 \\
\hline 15 & -2.5 \\
\hline 16 & 0 \\
\hline 17 & 0 \\
\hline 18 & 0 \\
\hline 19 & 0 \\
\hline 20 & -3.0 \\
\hline 21 & 0 \\
\hline 22 & -1.7 \\
\hline 23 & 0 \\
\hline 24 & 0 \\
\hline & \\
\hline
\end{tabular}

Table 3: Physical and economical data

\begin{tabular}{|l|l|}
\hline Input pressure & $10^{6} \mathrm{~Pa}$ \\
\hline Input fluid temperature & $110^{\circ} \mathrm{C}$ \\
\hline Output fluid temperature & $70{ }^{\circ} \mathrm{C}$ \\
\hline Density & $934.8 \mathrm{~kg} / \mathrm{m}^{3}$ \\
\hline Kinematics viscosity & $0.226 \times 10^{-6} \mathrm{~m}^{2} / \mathrm{s}$ \\
\hline Operating time & $8760 \mathrm{~h} / \mathrm{a}$ \\
\hline Interest rate & 0.1 \\
\hline Price of electrical energy & $7.1 \times 10^{-5} \mathrm{EUR} / \mathrm{Wh}$ \\
\hline Pump price & $0.15 \mathrm{EUR} / \mathrm{W}$ \\
\hline Pumps lifetime & 10 year \\
\hline Pumps efficiency & 0.75 \\
\hline Pipe network lifetime & 40 year \\
\hline Pipe roughness & $0.4 \mathrm{~mm}$ \\
\hline Coefficient of pipe costs polynomial: \\
\hline A & $18 \mathrm{EUR}$ \\
\hline B & $291 \mathrm{EUR} / \mathrm{m}$ \\
\hline C & $229 \mathrm{EUR} / \mathrm{m}^{2}$ \\
\hline Coefficient of construction costs polynomial: \\
\hline D & $287 \mathrm{EUR}$ \\
\hline E & $310 \mathrm{EUR} / \mathrm{m}$ \\
\hline F & $1275 \mathrm{EUR} / \mathrm{m}^{2}$ \\
\hline
\end{tabular}

\section{Results and discussion}

By using the developed computer programme, which enables optimization of the pipe network using the simplex method two optimal branch trees was defined.

The first optimal branch tree, Figure 7 and tables 4, 5, 6 , was received by Version 1 . This is for the case when at passage on standard diameters we consider only pipe costs while in objective function we consider all costs $\left(\mathrm{C}_{1}, \mathrm{C}_{2}, \mathrm{C}_{3}\right.$ and $\mathrm{C}_{4}$ ).

Table 4: Output pressure in nodes

\begin{tabular}{|c|l|c|l|}
\hline Node & $\mathrm{p}[\mathrm{Pa}]$ & Node & $\mathrm{p}[\mathrm{Pa}]$ \\
\hline 1 & 1000000 & 13 & 929678. \\
\hline 2 & 989448. & 14 & 911975. \\
\hline 3 & 899868. & 15 & 921361. \\
\hline 4 & 932760. & 16 & 934913. \\
\hline 5 & 947095. & 17 & 954457. \\
\hline 6 & 972226. & 18 & 923717. \\
\hline 7 & 967123. & 19 & 901952. \\
\hline 8 & 959943. & 20 & 875753. \\
\hline 9 & 944151. & 21 & 851575. \\
\hline 10 & 988733. & 22 & 858976. \\
\hline 11 & 969521. & 23 & 891215. \\
\hline 12 & 956542. & 24 & 921451 \\
\hline
\end{tabular}

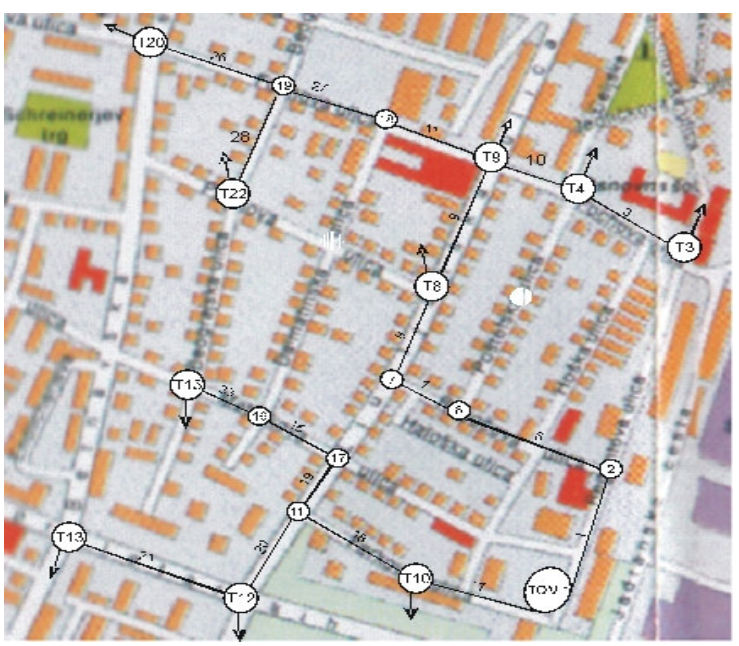

Figure 7: Optimised branch tree path of the district heating system 


\section{ACCEPTED MANUSCRIPT}

The subjects of table 5 are the pipe diameters, volume flows, flow velocities and pressure fall on particular pipe segments. The costs of pipes, pumps, pumping, construction work and common costs of first optimal branch tree path are defined by the cost capitalisation method and are presented for each pipe in table 6 .

Table 5: Optimisation results by the first version

\begin{tabular}{|c|c|c|c|c|}
\hline Pipe & $\begin{array}{c}\mathrm{D} \\
{[\mathrm{m}]}\end{array}$ & $\begin{array}{c}\mathrm{q}_{\mathrm{v}} \\
{\left[\mathrm{m}^{3} / \mathrm{s}\right]}\end{array}$ & $\begin{array}{c}\mathrm{v} \\
{[\mathrm{m} / \mathrm{s}]}\end{array}$ & $\begin{array}{c}\Delta \mathrm{p} \\
{[\mathrm{Pa}]}\end{array}$ \\
\hline 1 & 0.2191 & 0.03160 & 0.838 & 10552. \\
\hline 3 & 0.0570 & 0.00220 & 0.862 & 32892 \\
\hline 6 & 0.1937 & 0.03160 & 1.072 & 17222 \\
\hline 7 & 0.2191 & 0.03160 & 0.838 & 5103 \\
\hline 8 & 0.2191 & 0.03160 & 0.838 & 7180 \\
\hline 9 & 0.1778 & 0.02180 & 0.878 & 15792 \\
\hline 10 & 0.11143 & 0.00980 & 0.955 & 11391 \\
\hline 11 & 0.0825 & 0.00470 & 0.879 & 20434 \\
\hline 15 & 0.0635 & 0.00250 & 0.789 & 19544 \\
\hline 17 & 0.1524 & 0.01590 & 0.872 & 11267 \\
\hline 18 & 0.1330 & 0.01250 & 0.900 & 19212 \\
\hline 19 & 0.0635 & 0.00250 & 0.789 & 15064 \\
\hline 20 & 0.1270 & 0.01000 & 0.789 & 12979 \\
\hline 21 & 0.0889 & 0.00520 & 0.838 & 26864 \\
\hline 26 & 0.0700 & 0.00300 & 0.780 & 26199 \\
\hline 27 & 0.0825 & 0.00470 & 0.879 & 21764 \\
\hline 28 & 0.0510 & 0.00170 & 0.832 & 42976 \\
\hline 33 & 0.0635 & 0.00250 & 0.789 & 13552 \\
\hline
\end{tabular}

Table 6: Capitalized costs

\begin{tabular}{|r|r|r|r|r|r|}
\hline Pi. & $\begin{array}{c}\text { CC1 } \\
\text { [EUR] }\end{array}$ & $\begin{array}{c}\text { CC2 } \\
{[\text { EUR] }}\end{array}$ & $\begin{array}{c}\text { CC3 } \\
{[\text { EUR] }}\end{array}$ & $\begin{array}{c}\text { CC4 } \\
{[\text { EUR] }}\end{array}$ & $\begin{array}{c}\Sigma C C \\
{[\text { EUR] }}\end{array}$ \\
\hline 1 & 19920 & 110 & 2760 & 89360 & 112150 \\
\hline 3 & 5420 & 20 & 600 & 47370 & 53410 \\
\hline 6 & 18660 & 180 & 4500 & 88840 & 112180 \\
\hline 7 & 9480 & 50 & 1330 & 42550 & 53410 \\
\hline 8 & 15180 & 70 & 1880 & 68080 & 85210 \\
\hline 9 & 16530 & 110 & 2850 & 82120 & 101610 \\
\hline 10 & 4990 & 40 & 920 & 31210 & 37160 \\
\hline 11 & 6240 & 30 & 790 & 45990 & 53050 \\
\hline 15 & 4210 & 20 & 400 & 35080 & 39710 \\
\hline 17 & 11070 & 60 & 1480 & 59530 & 72140 \\
\hline 18 & 11180 & 80 & 1990 & 64570 & 77820 \\
\hline 19 & 3440 & 10 & 310 & 28700 & 32460 \\
\hline 20 & 8400 & 40 & 1070 & 49670 & 59180 \\
\hline 21 & 10740 & 50 & 1160 & 76350 & 88300 \\
\hline 26 & 7270 & 30 & 650 & 57970 & 65920 \\
\hline 27 & 6680 & 30 & 850 & 49280 & 56840 \\
\hline 28 & 5810 & 20 & 600 & 53220 & 59650 \\
\hline 33 & 3060 & 10 & 280 & 25510 & 28860 \\
\hline$\sum$ & 168280 & 960 & 24420 & 995400 & 1189060 \\
\hline
\end{tabular}

The second optimal branch tree, Figure 8 and tables 7, 8,9 was received by Version 2. This is for the case when at passage on standard diameters we consider pipe costs while in objective function we consider only $\mathrm{C}_{1}, \mathrm{C}_{2}, \mathrm{C}_{3}$.

Table 7: Output pressure in nodes by second version

\begin{tabular}{|c|c|c|c|}
\hline Node & $\mathrm{p}[\mathrm{Pa}]$ & Node & $\mathrm{p}[\mathrm{Pa}]$ \\
\hline 1 & 1000000 & 13 & 929678 \\
\hline 2 & 989448. & 14 & 911975 \\
\hline 3 & 900614 & 15 & 921361 \\
\hline 4 & 933506 & 16 & 934913 \\
\hline 5 & 949518 & 17 & 954457 \\
\hline 6 & 972226 & 18 & 914753 \\
\hline 7 & 965478 & 19 & 893868 \\
\hline 8 & 952674 & 20 & 967669 \\
\hline 9 & 934341 & 21 & 869284 \\
\hline 10 & 988733 & 22 & 876685 \\
\hline 11 & 969521 & 23 & 891215 \\
\hline 12 & 956542 & 24 & 914182 \\
\hline
\end{tabular}

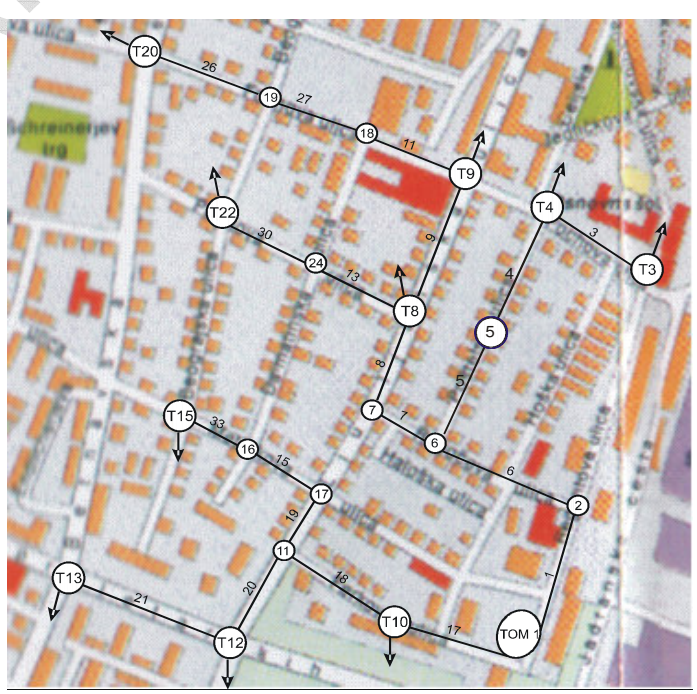

Figure 8: Optimised branch tree path of the district heating system by second version 


\section{ACCEPTED MANUSCRIPT}

Table 8: Optimisation results by the second version

\begin{tabular}{|r|l|l|l|l|}
\hline Pipe & $\begin{array}{c}\text { D } \\
{[\mathrm{m}]}\end{array}$ & $\begin{array}{c}\mathrm{q}_{\mathrm{v}} \\
{\left[\mathrm{m}^{3} / \mathrm{s}\right]}\end{array}$ & $\begin{array}{c}\mathrm{v} \\
{[\mathrm{m} / \mathrm{s}]}\end{array}$ & $\begin{array}{c}\Delta \mathrm{p} \\
{[\mathrm{Pa}]}\end{array}$ \\
\hline 1 & 0.2191 & 0.03160 & 0.838 & 10552 \\
\hline 3 & 0.0570 & 0.00220 & 0.862 & 32892 \\
\hline 4 & 0.1270 & 0.00980 & 0.774 & 16012 \\
\hline 5 & 0.1143 & 0.00980 & 0.955 & 22708 \\
\hline 6 & 0.1937 & 0.03160 & 1.072 & 17222 \\
\hline 7 & 0.1778 & 0.02180 & 0.878 & 6748 \\
\hline 8 & 0.1683 & 0.02180 & 0.9801 & 12804 \\
\hline 9 & 0.1270 & 0.01030 & 0.813 & 18333 \\
\hline 11 & 0.0700 & 0.00300 & 0.780 & 19588 \\
\hline 13 & 0.0510 & 0.00170 & 0.832 & 38492 \\
\hline 15 & 0.0635 & 0.00250 & 0.789 & 19544 \\
\hline 17 & 0.1524 & 0.01590 & 0.872 & 11267 \\
\hline 18 & 0.1330 & 0.01250 & 0.900 & 19212 \\
\hline 19 & 0.0635 & 0.00250 & 0.789 & 15064 \\
\hline 20 & 0.1270 & 0.0100 & 0.789 & 1279 \\
\hline 21 & 0.0889 & 0.00520 & 0.838 & 26864 \\
\hline 26 & 0.0700 & 0.00300 & 0.780 & 26199 \\
\hline 27 & 0.0700 & 0.00300 & 0.780 & 20886 \\
\hline 30 & 0.0510 & 0.00170 & 0.832 & 37497 \\
\hline 33 & 0.0635 & 0.00250 & 0.789 & 13552 \\
\hline
\end{tabular}

Table 9: Capitalized costs by the second version

\begin{tabular}{|r|c|c|c|c|c|}
\hline Pi. & $\begin{array}{c}\text { CC1 } \\
{[\text { EUR] }}\end{array}$ & $\begin{array}{c}\text { CC2 } \\
{[\text { EUR] }}\end{array}$ & $\begin{array}{c}\text { CC3 } \\
{[\text { EUR] }}\end{array}$ & $\begin{array}{c}\text { CC4 } \\
{[\text { EUR] }}\end{array}$ & $\begin{array}{c}\Sigma C C \\
{[\text { EUR] }}\end{array}$ \\
\hline 1 & 19920 & 110 & 2760 & 0 & 22790 \\
\hline 3 & 5420 & 20 & 60 & 0 & 5500 \\
\hline 4 & 12000 & 50 & 1300 & 0 & 13350 \\
\hline 5 & 11100 & 70 & 1840 & 0 & 13010 \\
\hline 6 & 18660 & 180 & 4500 & 0 & 23340 \\
\hline 7 & 7870 & 50 & 1220 & 0 & 9140 \\
\hline 8 & 12020 & 90 & 2310 & 0 & 14420 \\
\hline 9 & 12590 & 60 & 1560 & 0 & 14210 \\
\hline 11 & 5650 & 20 & 490 & 0 & 6160 \\
\hline 13 & 5130 & 20 & 540 & 0 & 5690 \\
\hline 15 & 4210 & 20 & 400 & 0 & 4630 \\
\hline 17 & 11070 & 60 & 480 & 0 & 11610 \\
\hline 18 & 11180 & 80 & 990 & 0 & 12250 \\
\hline 19 & 3440 & 10 & 310 & 0 & 3760 \\
\hline 20 & 8400 & 40 & 70 & 0 & 8510 \\
\hline 21 & 10740 & 50 & 160 & 0 & 10950 \\
\hline 26 & 7270 & 30 & 650 & 0 & 7950 \\
\hline 27 & 6060 & 20 & 520 & 0 & 6600 \\
\hline 30 & 5470 & 20 & 530 & 0 & 6020 \\
\hline 33 & 3060 & 10 & 280 & 0 & 3350 \\
\hline$\sum$ & 181260 & 1010 & 20970 & 0 & 203240 \\
\hline
\end{tabular}

Of some interest are the influences of price changes of construction work, pumps and electrical energy regarding the course and characteristics of the branch tree pipe network.
With equal construction and pump costs, if the costs of electric energy increase by $50 \%$ we get by the first version the third path (Figure 9) and by the second version second path.

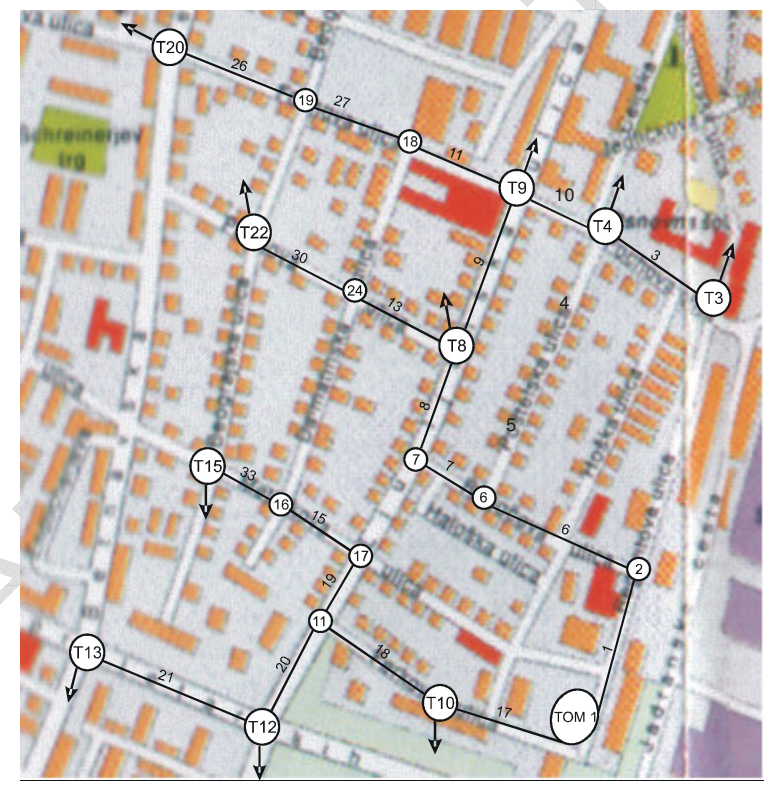

Figure 9: The third optimised branch tree path

Analysing the situation, when the prices for electrical energy and construction work remain the same but the pump price changes, we conclude that by both version the paths are unchanged (version $1-1^{\text {st }}$ path, version $2-2^{\text {nd }}$ ).

\section{Conclusion}

Determination by the optimal tree branch path was executed using the simplex method. The basic factors for determination of the path are economy and functionality of the tree pipe network. Because the solution of nonlinear systems requires the use of computers, a computer 
programme was developed, which considers all the limitations and requests of the given case.

The programme enables, after the determination of the optimal branch tree path and capitalised costs, also variations of different influential parameters and the evaluation of their influence on the district heating system as a whole. The optimal path, defined by the programme is not necessarily the shortest path, due to the fact that the branch tree pipe network is a function of the minimising both the investment and operational costs.

Within defining the optimal branch tree path the results show the importance of which costs do we consider into objective function and which costs do we use at passage on standard pipe diameters, also the construction and operating costs of the system have important role. The path itself varies with the changing of construction costs, pump and electric energy costs. With their increase the investment, operational and maintenance costs also go up.

Therefore using the simplex method for each sole case the solution, representing the most reasonable fluid transport path from entering nodes to exiting nodes, was selected.

\section{References}

[1] H. Yoshino, Y. Yoshino, Q. Zhang, A. Mochida, Li N, Li Z, Miyasaka H., Indoor thermal environment and energy saving for urban residential buildings in China, Energy and buildings 38 (2006) 1308 - 1319.
[2] D. Goricanec, J. Krope, A. Jakl, Determining the commercially available thermal insulation thickness of pipe systems, V. V. International HVAC $+\mathrm{R}$ technology symposium, 2002.

[3] M. Umberger, T. Krope, J. Krope, Energy economy and the protection of environment with building-in insulated windows, WSEAS transactions on heat and mass transfer 1 (1) (2006) 32-38.

[4] J. Krope, D. Dobersek, D. Goricanec, Economic evaluation of possible use of heat of flue gases in a heating plant, WSEAS transactions on heat and mass transfer 1 (1) (2006) 75-80.

[5] Hetaing Handbook, McGrew Hill, 1999.

[6] D. Goricanec , J. Krope, Dimensioning and design of tree path transport pipe networks, Proceedings of "Power and Energy Systems", 7 (2003) 327-331.

[7] Dobersek, D., Goricanec, D., Krope, J., Calibration of pipe networks for district heating using the nonlinear optimisation method, International Journal of Nonlinear Sciences and Numerical Simulation 7 (2) (2006) 225-228.

[8] Saul I. Gass, Linear Programming Methods and Aplications, fifth ed., McGrew - Hill, 1985.

[9] O. Levenspiel, Engineering Flow and Heat Exchange, Revised ed. Plenum Press, 1998.

[10] Garbai L., Börzsönyi, A., Krope, J., The Economic Optimum Of The Setting Up Of Loop District Heating Networks, Energia és Atomtechnika, XLII. évf. 2. szám. 1989. 
[11] Krope A., Krope J., Ticar I.,. Zmanjšanje tlačnih izgub $\mathrm{v}$ vročevodnih cevnih mrežah $=$ The reduction of friction losses in district-heating pipelines, Journal of mechanical engineering (46) 8, (2000) 525-531.

[12] J.A. Roberson, C.T. Crowe, Engineering fluid mechanics, sixth ed., John Wiley \& Sons, Inc. New York, 1997.

[13] D. Goricanec, J. Krope, A. Krope, A. Jakl, Software application for determining the thermal insulation thickness of pipe systems. V: BOURKAS, P.D. (ur.). 6th IASTED International Conference Power and Energy Systems, July 3-6, 2001, Rhodes, Greece. Acta Press ( 2001) 549-553.

[14] Hillier S. Frederick, Lieberman J. Gerald, Introduction to mathematical programming, second ed., McGraw-Hill, 1995.

[15] Dantzig George B., Linear Programming and Extensions, eleventh printing, Princeton, New Jersey Princeton University Press, 1998.
[16] G. Sierksma, Linear and integer programming: Theory and practice, Marcel Dekker, Inc., New York, 1996.

[17] Garbai, L., Molnár, L., Optimizing Problems Of Loop District Heating Networks, Energia és Atomtechnika, XXVIII. évf. (1975).

[18] Garbai L., Dezso Gy., Flow In Energy Pipe Network Systems Muszaki Könyvkiadó, Budapest, 1986.

[19] Bellmann T. E., Dynamic Programming Princeton University Press, Princeton, 1962.

[20] Kurtz M, Handbook of engineering economics, McGraw- Hill, 1984.

[21] A. Pristovnik., D. Goricanec, J. Krope, Two-phase flow in pipe line systems. Heating and airconditioning of buildings. Energy and environment : proceedings of the Third SITHOK-3 International Congress, Maribor, Slovenia. (1998)351-359. 
Figure captions

Figure 1: Relationship between $\mathrm{CC}$ and $\mathrm{q}_{\mathrm{y}}$

Figure 2: Relationship between all annuity costs vs. pipe diameter

Figure 3: Loop pipe network of all possible routes of the district heating system

Figure 4:Optimised branch tree path of the district heating system

Figure 5: Optimised branch tree path of the district heating system by second version

Figure 6: The third optimised branch tree path

Table captions

Table 1: Pipe data

Table 2: Input and output data nodes

Table 3: Physical and economical data

Table 4: Output pressure in nodes

Table 5: Optimisation results by the first version

Table 6: Capitalized costs

Table 7: Output pressure in nodes by second version

Table 8: Optimisation results by the second version

Table 9: Capitalized costs by the second version 